\title{
Determination of Dehydrogenase Activities Involved in D-Glucose Oxidation in Gluconobacter and Acetobacter Strains
}

Florencia Sainz ${ }^{1}$, María Jesús Torija ${ }^{*}$, Minenosuke Matsutani ${ }^{2}$, Naoya Kataoka²,
Toshiharu Yakushi ${ }^{2}$, Kazunobu Matsushita ${ }^{2}$ and Albert Mas ${ }^{*}$

${ }^{1}$ Departament de Bioquímica i Biotecnologia, Facultat d'Enologia, Universitat Rovira i Virgili, Tarragona, Spain, ${ }^{2}$ Department of Biological Chemistry, Faculty of Agriculture, Yamaguchi University, Yamaguchi, Japan

Acetic acid bacteria (AAB) are known for rapid and incomplete oxidation of an extensively variety of alcohols and carbohydrates, resulting in the accumulation of organic acids as the final products. These oxidative fermentations in AAB are catalyzed by $P Q Q$ - or FAD- dependent membrane-bound dehydrogenases. In the present study, the enzyme activity of the membrane-bound dehydrogenases [membranebound $P Q Q$-glucose dehydrogenase $(\mathrm{mGDH})$, D-gluconate dehydrogenase (GADH) and membrane-bound glycerol dehydrogenase $(G L D H)]$ involved in the oxidation of D-glucose and D-gluconic acid (GA) was determined in six strains of three different species of $A A B$ (three natural and three type strains). Moreover, the effect of these activities on the production of related metabolites [GA, 2-keto-D-gluconic acid (2KGA) and 5-keto-D-gluconic acid (5KGA)] was analyzed. The natural strains belonging to Gluconobacter showed a high mGDH activity and low activity in GADH and GLDH, whereas the Acetobacter malorum strain presented low activity in the three enzymes. Nevertheless, no correlation was observed between the activity of these enzymes and the concentration of the corresponding metabolites. In fact, all the tested strains were able to oxidize D-glucose to GA, being maximal at the late exponential phase of the AAB growth (24 h), which coincided with D-glucose exhaustion and the maximum mGDH activity. Instead, only some of the tested strains were capable of producing 2KGA and/or 5KGA. In the case of Gluconobacter oxydans strains, no 2KGA production was detected which is related to the absence of GADH activity after $24 \mathrm{~h}$, while in the remaining strains, detection of GADH activity after $24 \mathrm{~h}$ resulted in a high accumulation of 2KGA. Therefore, it is possible to choose the best strain depending on the desired product composition. Moreover, the sequences of these genes were used to construct phylogenetic trees. According to the sequence of gcd, gene coding for mGDH, Acetobacter and Komagataeibacter were phylogenetically more closely related each other than with Gluconobacter. 


\section{INTRODUCTION}

Acetic acid bacteria (AAB) are gram-negative, ellipsoidal to rodshape acidophilic bacteria and are obligate aerobes (De Ley and Swings, 1984; Deppenmeier et al., 2002). These bacteria could occur in sugary natural environments such as fruits, honey bees, or flowers and in artificial and manmade environments such as soft drinks, cider, beer, wine, or vinegar (De Ley and Swings, 1984). AAB are well known for the rapid and incomplete oxidation of a broad range of sugars, sugar alcohols, and sugar acids (such as D-glucose, glycerol, D-sorbitol, ethanol, or Dgluconic acid) resulting in the accumulation of high amounts of the oxidized products in the culture medium (Asai, 1968; Deppenmeier et al., 2002; Elfari et al., 2005). This capacity allows for the use of $\mathrm{AAB}$ for a variety of biotechnological processes in which they carry out oxidative fermentation to obtain several useful compounds that are difficult to be prepared with chemical processes or to be produced with high yields (Gupta et al., 2001; Deppenmeier et al., 2002). Some examples of this metabolism are the production of acetic acid from ethanol or D-gluconic acid (GA) from D-glucose (Deppenmeier et al., 2002; Prust et al., 2005; Lino et al., 2012). Most of these oxidative reactions are catalyzed by membrane-bound dehydrogenases, with reactive centers that are oriented to the periplasmic space (Matsushita et al., 1994). This implies that transport of substrates inside the cell is unnecessary and accumulation of oxidized products in the medium is rapid and near-quantitative (Deppenmeier et al., 2002; Adachi et al., 2003; Matsushita et al., 2003; Elfari et al., 2005; Merfort et al., 2006).

In $\mathrm{AAB}$, many membrane-bound oxidoreductases have been described, and most of these oxidoreductases are pyrroloquinoline quinone (PQQ-) or flavin (FAD-) dependent proteins (Saichana et al., 2015). The oxidative reaction with these dehydrogenases results in bioenergy for $\mathrm{AAB}$ because electrons extracted from the substrates are transferred via ubiquinone to the terminal ubiquinol oxidase (Adachi et al., 2007). In D-glucose oxidation, several enzymes located on the periplasmic face of the cytoplasmic membrane catalyze D-glucose oxidation sequentially. Membrane-bound PQQ-glucose dehydrogenase $(\mathrm{mGDH})$ oxidizes D-glucose to glucono- $\delta$-lactone, and it is then converted to GA by glucono- $\delta$-lactonase or spontaneously (Matsushita et al., 1994; Shinagawa et al., 1999). Therefore, $\mathrm{mGDH}$ is the enzyme responsible for the production of most GA from D-glucose during fermentation (Macauley et al., 2001). GA can be further converted to 2-keto-D-gluconic acid (2KGA) or 5keto-D-gluconic acid (5KGA) by two different membrane-bound dehydrogenases (Matsushita et al., 1994; Saichana et al., 2015). One protein is D-gluconate dehydrogenase (GADH), which is a FAD-dependent enzyme (flavoprotein-cytochrome $c$ complex) reacting with GA as its only substrate and is responsible for the oxidation of GA to 2KGA (Matsushita et al., 1994; Adachi et al., 2007; Toyama et al., 2007). The membrane-bound dehydrogenase involved in the 5KGA production has been unidentified for a long time, and no specific 5KGA-yielding gluconate dehydrogenase has been found in AAB. Instead, it has been shown that this reaction is catalyzed by a glycerol or polyol dehydrogenase (GLDH, membrane-bound glycerol dehydrogenase), which shows a broad substrate specificity toward several sugar alcohols (D-glycerol, D-sorbitol, D-arabitol, or D-mannitol). Therefore, it is concluded that other PQQdependent dehydrogenases such as D-arabitol dehydrogenase $(\mathrm{ARDH})$ or D-sorbitol dehydrogenase (SLDH) are identical to GLDH (Matsushita et al., 2003; Adachi et al., 2007). 2KGA could be further oxidized to 2,5-diketo-D-gluconate by the FAD-dependent 2-keto-D-gluconate dehydrogenase (2KGDH), which is characterized as a flavoprotein-cytochrome $c$ complex with three different subunits similar to GADH.

We have developed a strawberry beverage in which D-glucose is completely fermented to GA or some other acids, yet fruit fructose is maintained as a natural sweetener (Cañete-Rodríguez et al., 2015, 2016). GA could be found naturally in fruit juices, honey, yogurt, bread, cottage cheese and meat. This acid gives a refreshing sour taste to wine and fruit juices and has the property of preventing bitterness in foodstuffs. In the food industry, GA is widely used as flavoring agent and for reducing absorption of fat products and is listed as a generally permitted food additive (E574) by the EFSA, and as a GRAS (Generally Recognized As Safe) additive by the US FDA (Ramachandran et al., 2006). Moreover, GA has been reported to have some beneficial effects on intestinal microbiota (Asano et al., 1994, 1997; Tsukahara et al., 2002) and it has limited toxicity. This low toxicity makes GA useful for food additives as one of the common counter ions for the administration of some metal cations $(\mathrm{Zn}, \mathrm{Ca}, \mathrm{Na}, \mathrm{K}$ ) or other chemicals (chlorhexidine). However, the equimolar conversion of D-glucose into GA and the high D-glucose concentrations in some fruits might recommend the reduction of GA by further oxidation. Therefore, the knowledge of the possible transformations of D-glucose into different metabolites would help control the levels of the different compounds in these transformed fruit beverages. In a previous study (Sainz et al., 2016), three natural $A A B$ strains were selected for this GA fermentation using different media and conditions, but especially focusing on the strawberry process. Two of these strains belong to the Gluconobacter genus: Gluconobacter japonicus strain CECT 8443 isolated from grape must (Navarro et al., 2013) and Gluconobacter oxydans strain Po5 isolated from wine vinegar (Vegas et al., 2010). The other strain from Acetobacter malorum (CECT 7742) was the only strain isolated from strawberry vinegar (Hidalgo et al., 2013).

The aim of the present study was to compare the enzyme activities of the membrane-bound dehydrogenases responsible for D-glucose and GA oxidations in six strains of three different $A A B$ species (selected strains from our collection and other strains from other culture collection strains). We wanted to analyze the effect of these enzyme activities on the production of the involved metabolites (GA, 2KGA and 5KGA) for better control of the production of these fermented beverages.

\section{MATERIALS AND METHODS}

\section{Microorganism and Culture Conditions}

Two strains of each AAB species (G. oxydans, G. japonicus and A. malorum) were used in this study (Table 1). For the preparation 
TABLE 1 | Strains used in this study.

\begin{tabular}{|c|c|c|c|}
\hline Species & Strain & Source & Reference \\
\hline \multirow{2}{*}{$\begin{array}{l}\text { Gluconobacter } \\
\text { japonicus }\end{array}$} & CECT 8443 & Grape must & Navarro et al., 2013 \\
\hline & NBRC $3271^{\top}$ & Myrica rubra (Fruit) & Malimas et al., 2009 \\
\hline \multirow{2}{*}{$\begin{array}{l}\text { Gluconobacter } \\
\text { oxydans }\end{array}$} & Po5 & Vinegar & Vegas et al., 2010 \\
\hline & $621 \mathrm{H}$ & - & De Ley, 1961 \\
\hline \multirow{2}{*}{$\begin{array}{l}\text { Acetobacter } \\
\text { malorum }\end{array}$} & CECT $7742^{a}$ & Strawberry vinegar & Hidalgo et al., 2013 \\
\hline & NBRC $108912^{\top}$ & Rotting apple & Cleenwerck et al., 2002 \\
\hline
\end{tabular}

Type strains. ${ }^{\text {a }}$ This strain has been incorrectly named CECT 7749 in previous studies (Hidalgo et al., 2013 and Sainz et al., 2016).

of the inocula, these strains were previously grown for $24 \mathrm{~h}$ in $5 \mathrm{~mL}$ potato media (Matsushita and Ameyama, 1982) with shaking at $28^{\circ} \mathrm{C}$. Experiments were performed in Erlenmeyer flasks of $500 \mathrm{~mL}$ with $100 \mathrm{~mL}$ media (30 g/L of D-glucose (Wako Pure Chem., Osaka, Japan), $40 \mathrm{~g} / \mathrm{L}$ of D-fructose (Wako Pure Chem.), $5 \mathrm{~g} / \mathrm{L}$ of polypeptone (Nihon Pharmaceutical Co., Ltd, Tokyo, Japan) and $5 \mathrm{~g} / \mathrm{L}$ of yeast extract (Oriental Yeast Co., Ltd, Tokyo, Japan)) and inoculated with $1 \mathrm{~mL}$ of the corresponding strain grown in potato media. The experiment was carried out in triplicate, with shaking (200 rpm) at $28^{\circ} \mathrm{C}$ and sampled at 24,48 , and $96 \mathrm{~h}$. Bacterial growth was measured by a Klett-Summerson photoelectric colorimeter with a red filter.

\section{Preparation of Membrane Fraction}

As explained previously, cells were harvested at 24, 48, and $96 \mathrm{~h}$. The total volume $(100 \mathrm{~mL})$ was centrifuged for $5 \mathrm{~min}$ at $10.600 \times g$, and the cells were washed twice with $50 \mathrm{mM}$ potassium phosphate buffer, pH 6.5 (1 g wet cells per 4-5 mL buffer). After washing, the pellets were stored for $24 \mathrm{~h}$ at $4^{\circ} \mathrm{C}$ and then resuspended in the same volume with the same buffer. The cell suspension was passed twice through a French pressure cell press (SIM AMINCO, Spectronic Instruments, Inc., Rochester, NY, USA) at 16.000 psi. Intact cells were removed with $10.000 \times g$ for $10 \mathrm{~min}$, and the supernatant was centrifuged at $100.000 \times g$ for $60 \mathrm{~min}$ at $4^{\circ} \mathrm{C}$. The resulting precipitate was resuspended in potassium phosphate buffer [1 $\mathrm{M}$ dipotassium phosphate (Wako Pure Chem.) and $1 \mathrm{M}$ monopotassium phosphate (Wako Pure Chem.), pH 6.5] (20 mL buffer per $1 \mathrm{~g}$ pellet) and homogenized with the same buffer in a glass homogenizer. In the case of GLDH, $10 \mathrm{mM}$ MES [2-(N-morpholino)ethanesulfonic acid, (Dojindo, Kumamoto, Japan)] - NaOH buffer was used. The resulting homogenate was considered the membrane fraction.

\section{Protein Determination}

The protein concentration was determined by a modified Lowry method (Dulley and Grieve, 1975) using bovine serum albumin (Sigma, Tokyo, Japan) as the standard.

\section{Assays of Enzyme Activity}

All enzymatic reactions were performed in triplicate and at $25^{\circ} \mathrm{C}$. $\mathrm{mGDH}$ and GLDH were assayed in the presence of phenazine methosulfate (PMS) (Wako Pure Chem.) and 2,6-dichlorophenol indophenol (DCIP) (Wako Pure Chem.) as electron acceptors, as described by Matsushita et al. (1980). The $1 \mathrm{~mL}$ reaction mixture contains $50 \mathrm{mM}$ potassium phosphate buffer ( $\mathrm{pH} 6.5), 8 \mathrm{mM}$ sodium azide (Wako Pure Chem.), $6.67 \mathrm{mM}$ DCIP, 6 mM PMS, $100 \mathrm{mM}$ D-glucose or glycerol (Wako Pure Chem.) as substrate and the membrane fraction. Some modifications were done for the GLDH assay; $10 \mathrm{mM}$ acetate buffer [10 $\mathrm{mM}$ sodium acetate trihydrate (Wako Pure Chem) and acetic acid (Wako Pure Chem) ( $\mathrm{pH}$ 6.0)] was used instead of potassium phosphate buffer. For the conversion of apo-enzyme to holo-enzyme, $3 \mathrm{mM}$ calcium chloride anhydrate (Wako Pure Chem.) and 0.1 $\mu$ M PQQ (Wako Pure Chem.) were added and incubated for $10 \mathrm{~min}$ in an ice bath. The enzyme activity was measured by the reduction of DCIP at $600 \mathrm{~nm}$. One unit of enzyme activity was defined as the amount of enzyme catalyzing the oxidation of $1 \mu \mathrm{mol}$ of substrate per min, which was calculated using the millimolar extinction coefficient of DCIP of 13.2 at $\mathrm{pH} 6.5$ and of 11.13 at $\mathrm{pH} 6.0$.

The enzyme activity of GADH and $2 \mathrm{KGDH}$ was measured according to Wood et al. (1962), using ferricyanide (Wako Pure Chem.) as an electron acceptor. The reaction mixture consists of $8 \mathrm{mM}$ sodium azide, $100 \mathrm{mM}$ ferricyanide, $100 \mathrm{mM} \mathrm{GA}$ (Sigma) or $2 \mathrm{KGA}$ (Sigma) as the substrate, the membrane fraction and McIlvaine buffer [a mixture of $0.1 \mathrm{M}$ citric acid (Wako Pure Chem.) and 0.2 M disodium hydrogen phosphate (Wako Pure Chem.), $\mathrm{pH} 4.5$ ] to a total volume of $1.0 \mathrm{~mL}$. The reaction started with the addition of ferricyanide solution, and after $10 \mathrm{~min}$, the reaction was stopped by adding $500 \mu \mathrm{L}$ of ferric-Dupanol reagent (Wako Pure Chem.). Twenty minutes later, $3.5 \mathrm{~mL}$ of water was added, and after mixing well, the absorbance at $600 \mathrm{~nm}$ was measured by a UV-1700 PharmaSpec spectrophotometer (UV-1700 PharmaSpec, Shimadzu, Kyoto, Japan). Under these assay conditions, 4 absorbance units corresponded to $1 \mu \mathrm{mol}$ of substrate oxidized.

\section{Determination of Substrates and Products by HPLC Analysis}

All metabolites were analyzed using high performance liquid chromatography (HPLC - Shimadzu). D-Glucose and D-fructose were quantified on a $\mathrm{Pb}^{2+}$-loaded cation-exchange column (SUGAR SP0810, 8.0 mm I.D. × 300 mm L, Shodex, Showa denko $\mathrm{KK}$, Kawasaki, Japan) at $80^{\circ} \mathrm{C}$ using distilled and deionized water as the mobile phase at a flow rate of $0.5 \mathrm{~mL} \cdot \mathrm{min}^{-1}$. Substances were detected with a refractive index detector. The retention times for D-glucose and D-fructose were 19.5 and $24.7 \mathrm{~min}$, respectively. GA, 5KGA, and $2 \mathrm{KGA}$ were quantified on an ionexclusion column (RSpak KC-811, 8.0 mm I.D. $\times 300$ mm L, Shodex, Showa denko KK, Kawasaki, Japan) at $60^{\circ} \mathrm{C}$ using $0.1 \%$ $(\mathrm{w} / \mathrm{v})$ phosphoric acid as the mobile phase at a flow rate of $0.4 \mathrm{~mL} \cdot \mathrm{min}^{-1}$. Substances were detected with an UV detector (SPD-M20A, Shimadzu SPD-M20A) at $210 \mathrm{~nm}$. The retention times of GA, 5KGA, and 2KGA were 18.8, 18.1, and $17.4 \mathrm{~min}$, respectively.

\section{Primer Design and PCR Conditions}

Genes coding for $\mathrm{mGDH}(g c d)$ and large subunits of $\mathrm{GADH}$ $(g n d \mathrm{~L}), \mathrm{GLDH}(\operatorname{sldA})$ and $2 \mathrm{KGDH}(k g d \mathrm{~L})$ were partially amplified to confirm their presence. For this reason, the primers 


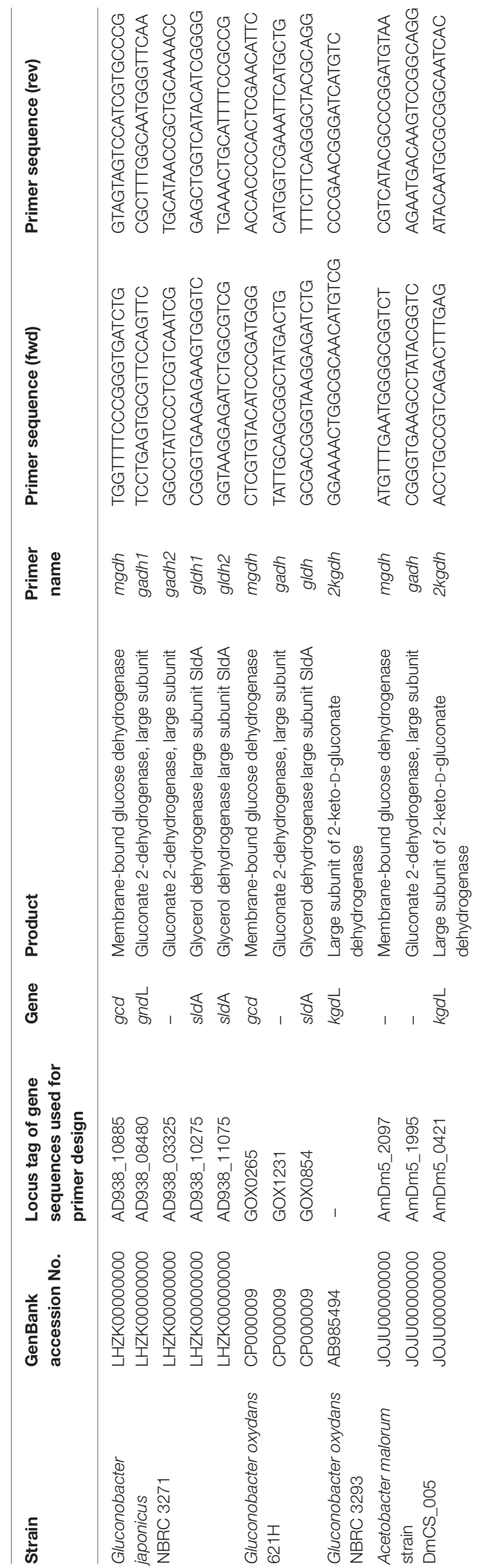

for these genes were designed using the program Primer3Plus (Untergasser et al., 2007) in each species using the sequences available in the GenBank database (Table 2). The amplification reaction was carried out in a total volume of $50 \mu \mathrm{L}$ consisting of $1 \mu \mathrm{L}$ of DNA solution, $5 \mu \mathrm{L}$ of $10 \mathrm{X}$ buffer, $3 \mu \mathrm{L}$ of $\mathrm{MgCl}_{2}$, $200 \mu \mathrm{M}$ each of the four dNTPs (Roche Diagnostic GmBh, Manheim, Germany), $0.4 \mu \mathrm{L}$ of BSA $(20 \mathrm{mg} / \mathrm{mL}), 4 \mu \mathrm{L}$ of DMSO, $1 \mu \mathrm{L}$ of each primer $(10 \mathrm{pmol})$, and $0.4 \mu \mathrm{L}$ of Taq Polymerase (Biotaq, Bioline - USA). The conditions of the PCR were as follows: initial denaturation at $94^{\circ} \mathrm{C}$ for $5 \mathrm{~min}$, followed by 30 cycles of denaturing at $94^{\circ} \mathrm{C}$ for $1 \mathrm{~min}$, annealing at $55^{\circ} \mathrm{C}$ or $60^{\circ} \mathrm{C}$ (depending on the primers) for $30 \mathrm{~s}$, extension at $72^{\circ} \mathrm{C}$ for $1 \mathrm{~min}$ and a final extension at $72^{\circ} \mathrm{C}$ for $10 \mathrm{~min}$ and maintained at $4^{\circ} \mathrm{C}$. The amplifications were performed in a Gene Amp PCR System 2700 (Applied Biosystems, Foster city, USA), and the PCR products were detected by electrophoresis gel on $1 \%$ agarose in 1X TBE buffer. The gels were stained with ethidium bromide and photographed.

\section{Sequence Alignment and Phylogenetic Tree Construction}

The nucleotide sequences of genes $g c d$ and $g n d \mathrm{~L}$ of the natural strains used in this study have been sequenced and deposited in the GenBank Database with the following accession numbers: G. oxydans Po5 (KU896941, KU896943), A. malorum CECT 7742 (Amal_02000,Amal_01874) and G. japonicus CECT 8443 (A0J51_02827, A0J51_00901). The sldA gene sequence was not found in A. malorum and the corresponding sequences for Gluconobacter species were A0J51_00428 and A0J51_00622 for G. japonicus and KU896942 for G. oxydans. These sequences were compared with the sequences from other genera and species available in GenBank database for the phylogenetic analyses. The sequence alignment was performed using the nucleotide sequence with the MUSCLE 3.8.31 software (Edgar, 2004a,b). The poorly aligned regions were removed using the Gblocks $0.91 \mathrm{~b}$ program (Castresana, 2000; Talavera and Castresana, 2007).

The phylogenetic tree was reconstructed using the maximum likelihood method implemented in the PhyML program (v3.1/3.0 aLRT). The HKY85 substitution model was selected assuming an estimated proportion of invariant sites (of 0.248) and 4 gammadistributed rate categories to account for rate heterogeneity across sites. The gamma shape parameter was estimated directly from the data $(\gamma=0.770)$. Reliability for internal branch was assessed using the aLRT test (SH-Like). The tree rendering was performed with the TreeDyn 198.3 graphical editor ${ }^{1}$ (Dereeper et al., 2008, 2010).

\section{RESULTS}

In this study, three selected $\mathrm{AAB}$ strains, belonging to G. japonicus, G. oxydans, and A. malorum species, isolated from vinegar or fruit were examined together with their corresponding culture collection strains in terms of growth, enzyme activities involved in the D-glucose oxidation, and metabolites produced

\footnotetext{
${ }^{1}$ http://www.phylogeny.fr
} 
from oxidation. For the G. japonicus species, both the isolated and the type culture strains showed very similar growth (Figure 1), achieving a high population at the end of the experiment (320 Klett units at $96 \mathrm{~h}$ ), without reaching the stationary phase. Both strains presented a high mGDH activity and a similar evolution over time (Figure 1A). In both cases, mGDH activity is maximal at $24 \mathrm{~h}$, although strain CECT 8443 exhibited twice the activity of NBRC 3271, and the activity decreased afterward. In relation to $\mathrm{GADH}$, both strains presented similar behavior, showing the highest activity at $24 \mathrm{~h}$ (Figure 1B). However, strain NBRC 3271 had fourfold higher activity than CECT 8443 during the first
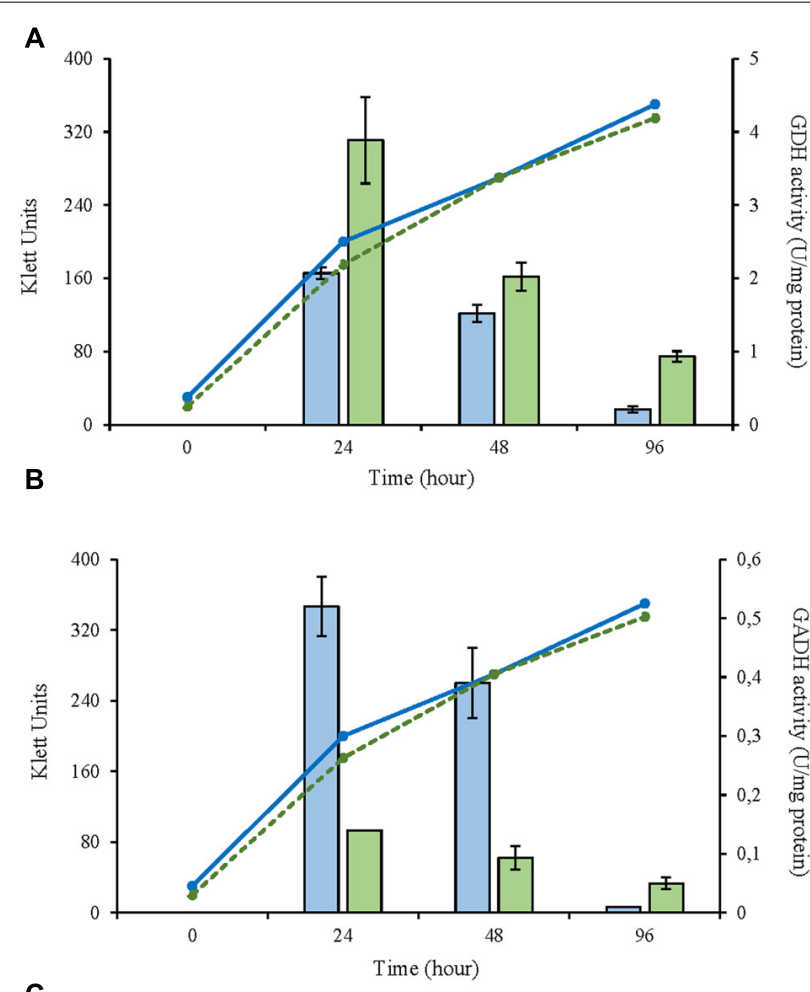

C

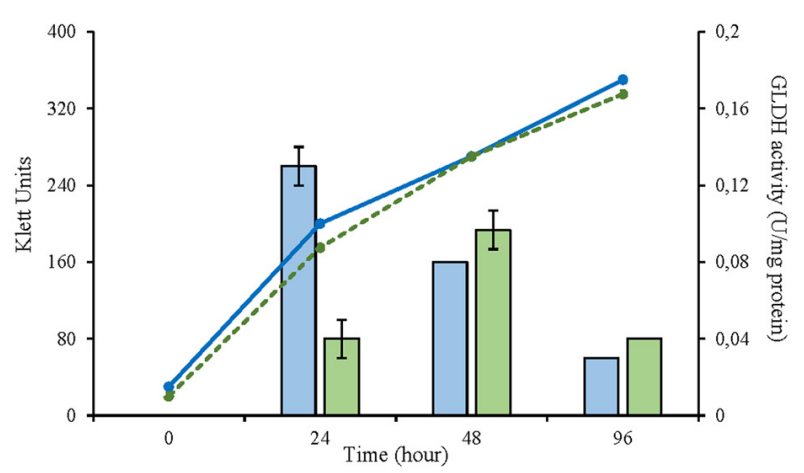

FIGURE 1 | Enzyme activity and growth (expressed in Klett units) of two Gluconobacter japonicus strains at three different growth stages (24, 48, and 96 h). (A) Glucose dehydrogenase activity (mGDH);

(B) Gluconate dehydrogenase activity (GADH); (C) Glycerol dehydrogenase activity (GLDH). Enzyme activity represented in bars: NBRC 3271 ( $\square$ ), CECT $8443(\square)$ and cell growth with lines: NBRC $3271(-)$; CECT $8443(--)$.
$48 \mathrm{~h}$ followed by a sharp decline, resulting in a GADH activity being practically absent at $96 \mathrm{~h}$. Instead, the GLDH activity in these strains presented low activity (lower than $0.15 \mathrm{U} / \mathrm{mg}$ protein in all the cases) and behaved differently from each other (Figure 1C). Strain NBRC 3271 presented the highest activity at $24 \mathrm{~h}$ and decreased afterward, whereas strain CECT 8443 exhibited the highest activity at $48 \mathrm{~h}$. The G. oxydans strains (Figure 2), although they had a very similar initial population, presented huge differences in their growth, mainly due to the first $24 \mathrm{~h}$, when strain $621 \mathrm{H}$ achieved twice the population of Po5. After this moment, the evolution in both strains was very similar, showing slower growth and entry in the stationary phase. Similarly, G. oxydans Po5 presented the highest activity of $\mathrm{mGDH}$ (Figure $\mathbf{2 A}$ ) at $24 \mathrm{~h}$, when maximal activity was reached, which was three times higher than in $621 \mathrm{H}$. Then, a clear decrease of the activity was observed in both cases. The GADH activity was only detected at $24 \mathrm{~h}$ in both $\mathrm{G}$. oxydans strains, with similar values $(\sim 0.1 \mathrm{U} / \mathrm{mg}$ protein) (Figure $2 \mathrm{~B})$. In the case of GLDH, G. oxydans strains showed similar activity at $24 \mathrm{~h}$ (Figure 2C), later presenting a reduction in the activity. However, in strain Po5, this decrease was more pronounced at $48 \mathrm{~h}$, but an upturn of activity was observed at the end ( 96 h). Finally, A. malorum strains presented a similar evolution of $G$. oxydans strains, although in this case the wild strain (CECT 7742) grew better than the type strain (NBRC 108912) (Figure 3). In this case, the difference in growth between both strains $(\sim 90$ Klett units) was mainly observed during the first $24 \mathrm{~h}$. After these $24 \mathrm{~h}$, CECT 7742 showed some growth, although with a lower rate, whereas the type strain was not growing. Strain NBRC 108912 showed a very high mGDH activity at $24 \mathrm{~h}$; however, no activity was detected afterward (Figure 3A). In contrast, CECT 7742 presented less activity but maintained the activity over time ( $1 \mathrm{U} / \mathrm{mg}$ protein at 24 and $48 \mathrm{~h}$ and half at $96 \mathrm{~h}$ ). The activity of GADH presented similar evolution as $\mathrm{mGDH}$, although with much lower values. In strain NBRC 108912, GADH activity was only detected at $24 \mathrm{~h}$, and with the highest value, whereas CECT 7742 presented a low and constant activity over time (Figure 3B). Finally, low GLDH activity was observed in both A. malorum strains (Figure 3C), although the activity was higher in NBRC 108912. In CECT 7742, residual activity was observed in all the points studied.

The activity of $2 \mathrm{KGDH}$ was also studied in all the strains. However, no activity was detected in any of these strains (Table 3).

In the tested strains, evolution of the metabolites derived from D-glucose oxidation was analyzed at the same time points when the enzymatic activity was measured (24, 48, and $96 \mathrm{~h})$. Similar patterns between strains of the same species were obtained according to the consumption and production of the metabolites studied. In G. japonicus and G. oxydans strains, D-glucose was totally exhausted at $24 \mathrm{~h}$, when the maximum accumulation of GA in the medium was observed (Figures 4A,B). Moreover, in G. japonicus strains, the depletion of D-glucose appeared to be correlated with the beginning of the oxidation of GA, resulting in the accumulation of $2 \mathrm{KGA}$ and $5 \mathrm{KGA}$ in the medium. Unlike what happened in strain NBRC 3271, where the initial accumulation of both keto-D-gluconates was similar, in 

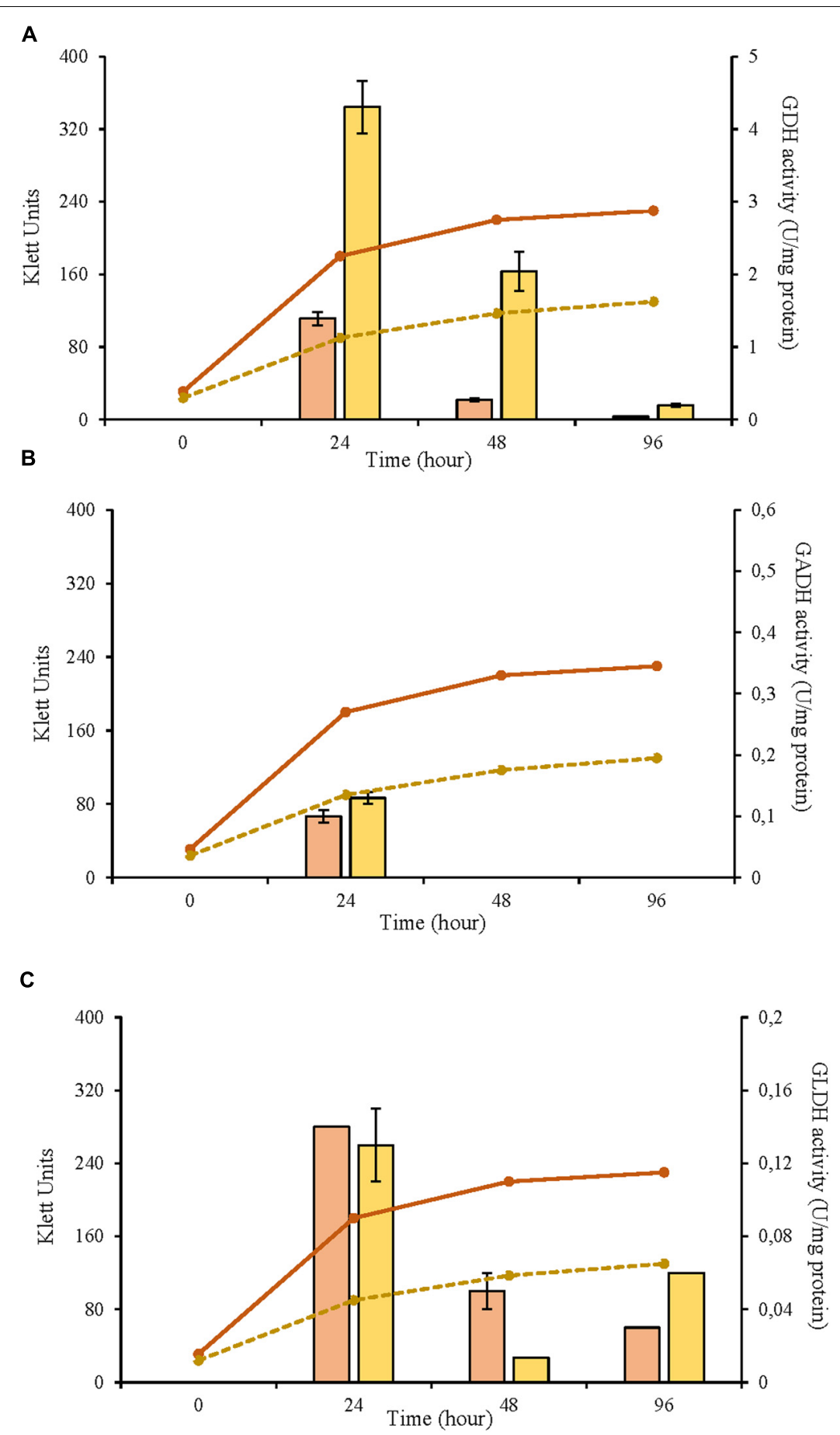

FIGURE 2 | Enzyme activity and growth (expressed in Klett units) of two Gluconobacter oxydans strains at three different growth stages (24, 48, and 96 h). (A) Glucose dehydrogenase activity (mGDH); (B) Gluconate dehydrogenase activity (GADH); (C) Glycerol dehydrogenase activity (GLDH); Enzyme activity represented in bars: $621 \mathrm{H}(\square)$, Po5 ( $($ ) and cell growth with lines: $621 \mathrm{H}(-)$; Po5 (--).

CECT 8443, (Figure 4B) the accumulation of 2KGA occurred before, not detecting 5KGA until $48 \mathrm{~h}$. Both G. japonicus strains accumulated more $2 \mathrm{KGA}$ than $5 \mathrm{KGA}$, although this difference was really remarkable in the type strain, in which the $2 \mathrm{KGA}$ concentration was three times higher than $5 \mathrm{KGA}$. The consumption of GA was not observed in G. oxydans strains, and it mostly accumulated in the medium (Figures 4C,D). However, strain $621 \mathrm{H}$ produced $5 \mathrm{KGA}$ in similar amounts to those obtained with G. japonicus NBRC 3271. This accumulation of 5KGA compensated for the lower accumulation of GA in this 


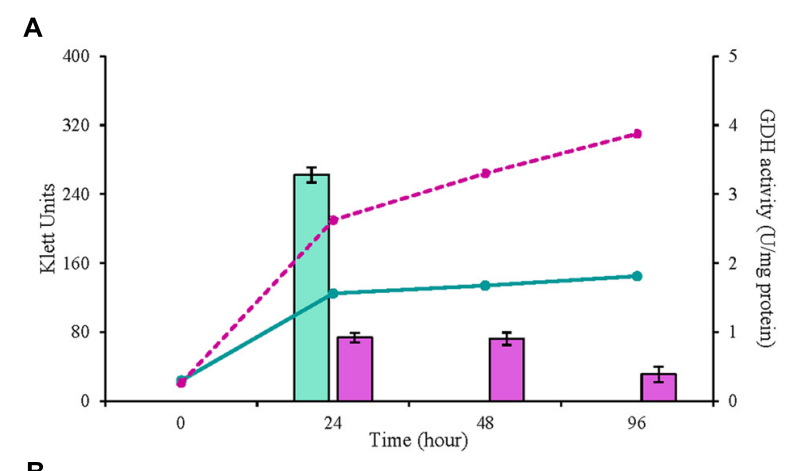

B

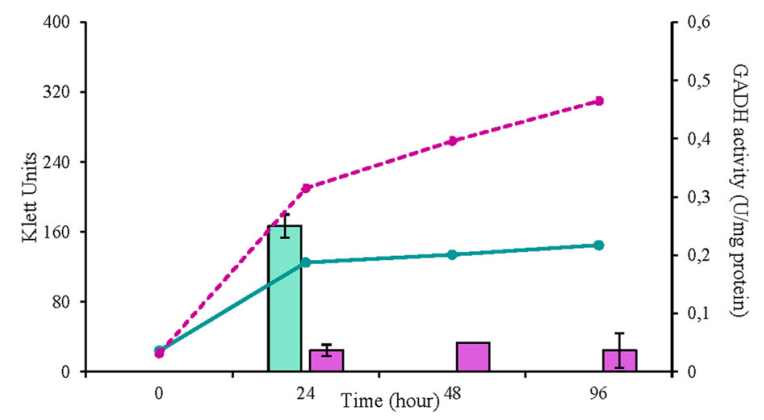

C

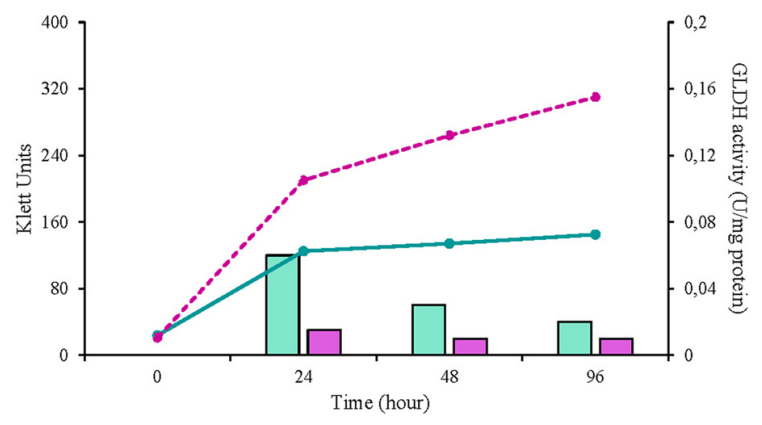

FIGURE 3 | Enzyme activity and growth (expressed in Klett units) of two Acetobacter malorum strains at three different growth stages (24, 48, and 96 h). (A) Glucose dehydrogenase activity (mGDH); (B) Gluconate dehydrogenase activity (GADH); (C) Glycerol dehydrogenase activity (GLDH). Enzyme activity represented in bars: NBRC $108912(\square)$, CECT 7742 ( $\square)$ and cell growth with lines: NBRC $108912(-)$; CECT 7742 (--). strain $621 \mathrm{H}$ compared with Po5. In the A. malorum strains, only NBRC 108912 (Figure 4E) consumed all D-glucose at the first $24 \mathrm{~h}$, whereas CECT 7742 (Figure 4F) consumed the substrate by $48 \mathrm{~h}$. Moreover, after the maximal accumulation of GA (24 h in both A. malorum strains), 56\% of GA produced was further oxidized in NBRC 108912, whereas only 19\% was further oxidized in CECT 7742. CECT 7742 accumulated four times more 2KGA than NBRC 108912.

The presence of the genes coding for the measured enzymes ( $g c d, g n d \mathrm{~L}$, sldA and $k g d \mathrm{~L}$ ) was confirmed by the amplification of a fragment of these genes. All primer sequences were designed from already available genome sequences of these three AAB species (see Table 2). In strain NBRC 3271, because two set of genes for GADH and GLDH are present, two sets of primers (gadh1 and gadh2; gldh1 and gldh2) were designed (Table 2). As expected, the presence of the genes for mGDH $(g c d)$ and GADH ( $g n d L)$ was confirmed for all the strains (Table 3). However, in strain G. japonicus CECT 8443, only one set of primers (gadh1) worked for the amplification of $g n d L$, and specific primers $(m g d h)$ for $g c d$ of NBRC 3271 did not work, although amplification was achieved with $G$. oxydans primers. In the case of the GLDH gene, no amplification was obtained in G. oxydans Po5 despite presenting activity, and in G. japonicus CECT 8443, as in GADH genes, only one set of primers (gldh2) worked. Finally, the $2 \mathrm{KGDH}$ gene $(\mathrm{kgdL})$ was amplified only in A. malorum strains, although activity was not detected.

Phylogenetic trees were constructed using the nucleotide sequences of these genes in these strains in comparison with sequences available in the GenBank Database (Figures 5-7). In all cases, $\mathrm{AAB}$ genera were clustered separately according to these gene sequences. In the case of the $\mathrm{mGDH}$ gene (Figure 5), two branches were clearly observed; one branch included the Komagataeibacter and Acetobacter species and the branch included the Gluconobacter and Asaia species. In the Acetobacter branch, both A. malorum enzymes grouped with A. orleanensis, A. senegalensis and A. tropicalis and were separated from those of A. pasteurianus, A. pomorum, A. ghanensis, A. syzygii and $A$. aceti. In the case of the Gluconobacter cluster, different species were mixed, and no specific groupings were observed. Our G. oxydans enzymes grouped together while our G. japonicus strains were separated in different subclusters. In the case of the GADH gene (Figure 6), the sequence of one of the genes (the one that was amplified with the set of primers gadh2)

TABLE 3 | Results of PCR analyses of gcd, gnd L, sldA, and $k g d L$ genes, and of enzyme activity for the six tested acetic acid bacteria strains.

\begin{tabular}{|c|c|c|c|c|c|c|c|c|c|}
\hline \multirow[b]{2}{*}{ Species } & \multirow[b]{2}{*}{ Strain } & \multicolumn{2}{|c|}{$g c d$} & \multicolumn{2}{|c|}{ gnd L } & \multicolumn{2}{|c|}{ sldA } & \multicolumn{2}{|c|}{ kgdL } \\
\hline & & Activity & Gene & Activity & Gene & Activity & Gene & Activity & Gene \\
\hline \multirow[t]{2}{*}{ Gluconobacter japonicus } & CECT 8443 & + & + & + & $+^{a}$ & + & $+^{b}$ & - & n.d \\
\hline & NBRC 3271 & + & + & + & + & + & + & - & n.d \\
\hline \multirow[t]{2}{*}{ Gluconobacter oxydans } & Po5 & + & + & + & + & + & - & - & - \\
\hline & $621 \mathrm{H}$ & + & + & + & + & + & + & - & - \\
\hline \multirow[t]{2}{*}{ Acetobactermalorum } & CECT 7742 & + & + & + & + & + & n.d & - & + \\
\hline & NBRC 108912 & + & + & + & + & + & n.d & - & + \\
\hline
\end{tabular}

n.d, not determined. a Amplified only by primers gadh1 (Table 2). ${ }^{\mathrm{b}}$ Amplified only by primers gldh2 (Table 2). 
A

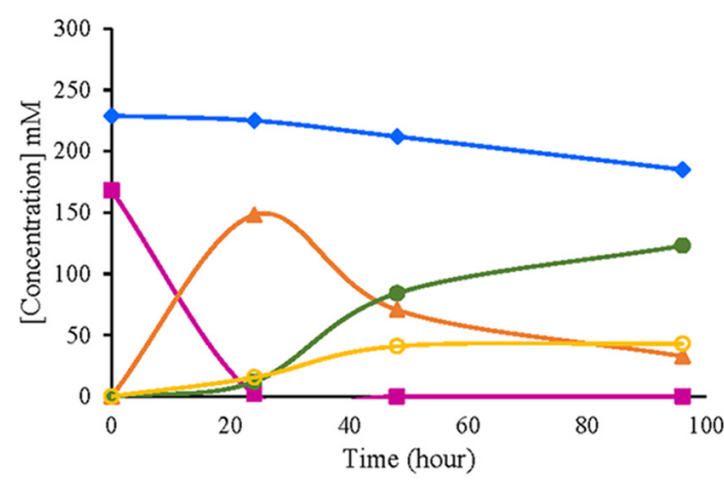

C

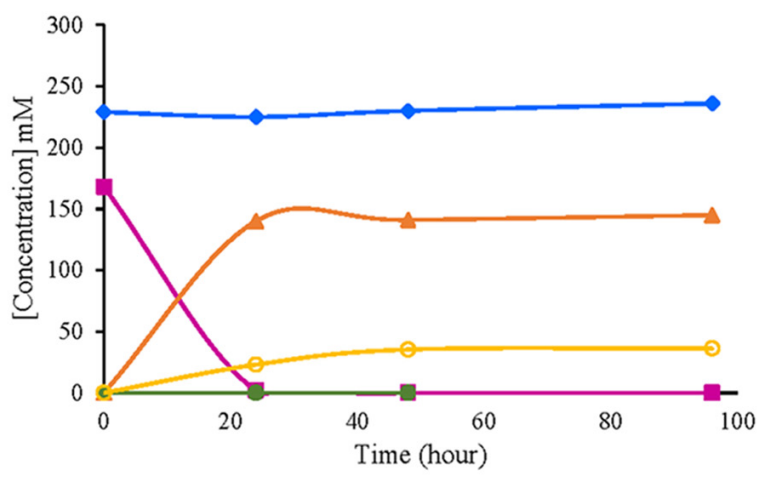

E

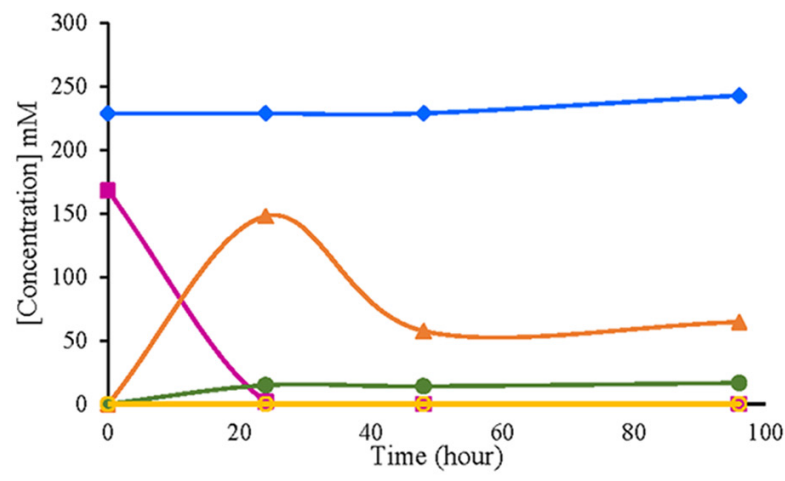

B

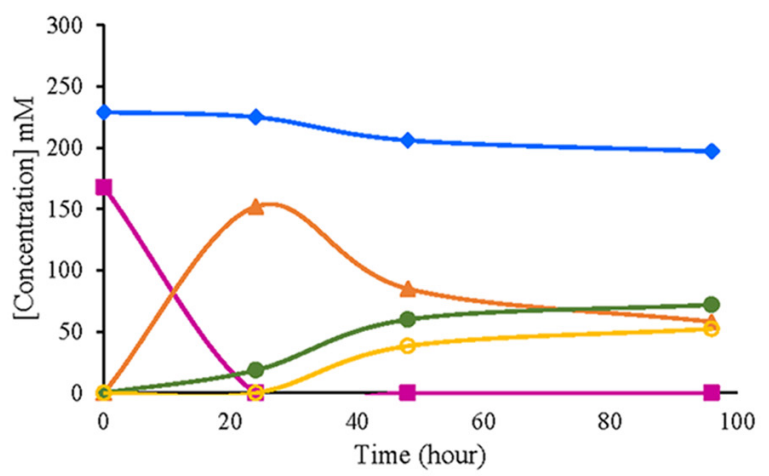

D

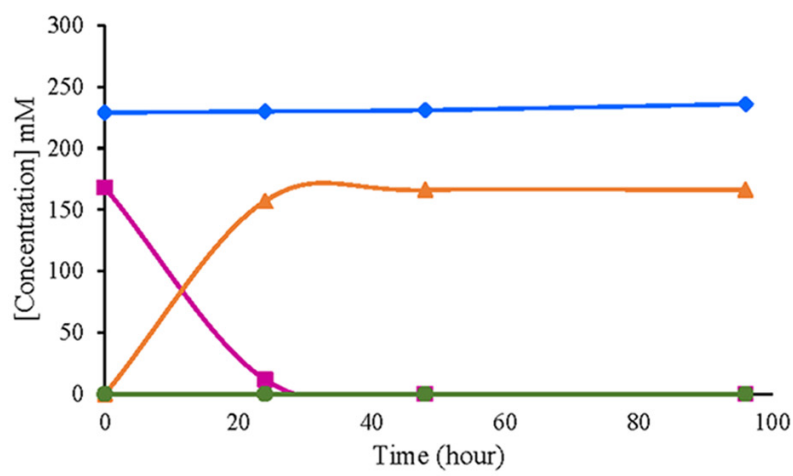

F

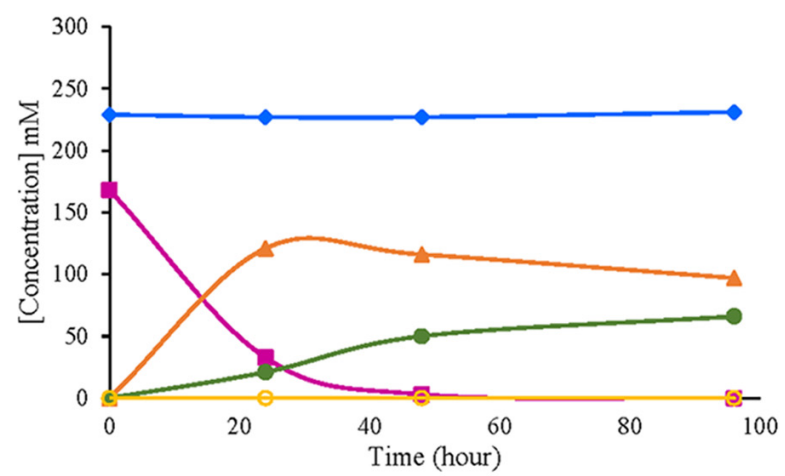

FIGURE 4 | Evolution of metabolites derived from D-glucose oxidation by six different strains of acetic acid bacteria. (A) Gluconobacter japonicus NBRC 3271; (B) Gluconobacter japonicus CECT 8443; (C) Gluconobacter oxydans 621H; (D) Gluconobacter oxydans Po5: (E) Acetobacter malorum NBRC 108912;

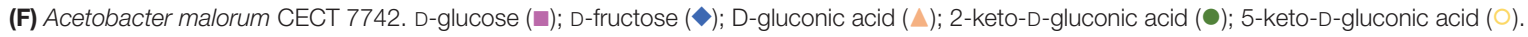

of G. japonicus NBRC 3271 appeared as outgroup. The other sequences were grouped in three clusters, one for Acetobacter species, another for Komagataeibacter species and the last one for Gluconobacter species together with one Asaia sequence. As in the mGDH tree, the two A. malorum enzymes grouped together. In the Gluconobacter cluster, there were two branches; one branch consisted of Asaia bogorensis sequence and gndL (which was amplified with set of primers gadh2) of a strain of G. oxydans (DSM 3504). All other sequences grouped together in a common branch. Finally, in the GLDH gene (sldA) tree (Figure 7), the sequences were grouped in two clusters; one branch included Gluconobacter sequences, and the other branch included Komagataeibacter and Asaia sequences. Unlike the other genes, in this case, the Asaia sequences clustered with Komagataeibacter but not with Gluconobacter. No Acetobacter sequences have been included because this gene has not been described in this genus. In the Gluconobacter cluster, three different groups were clearly defined; one cluster was basically 


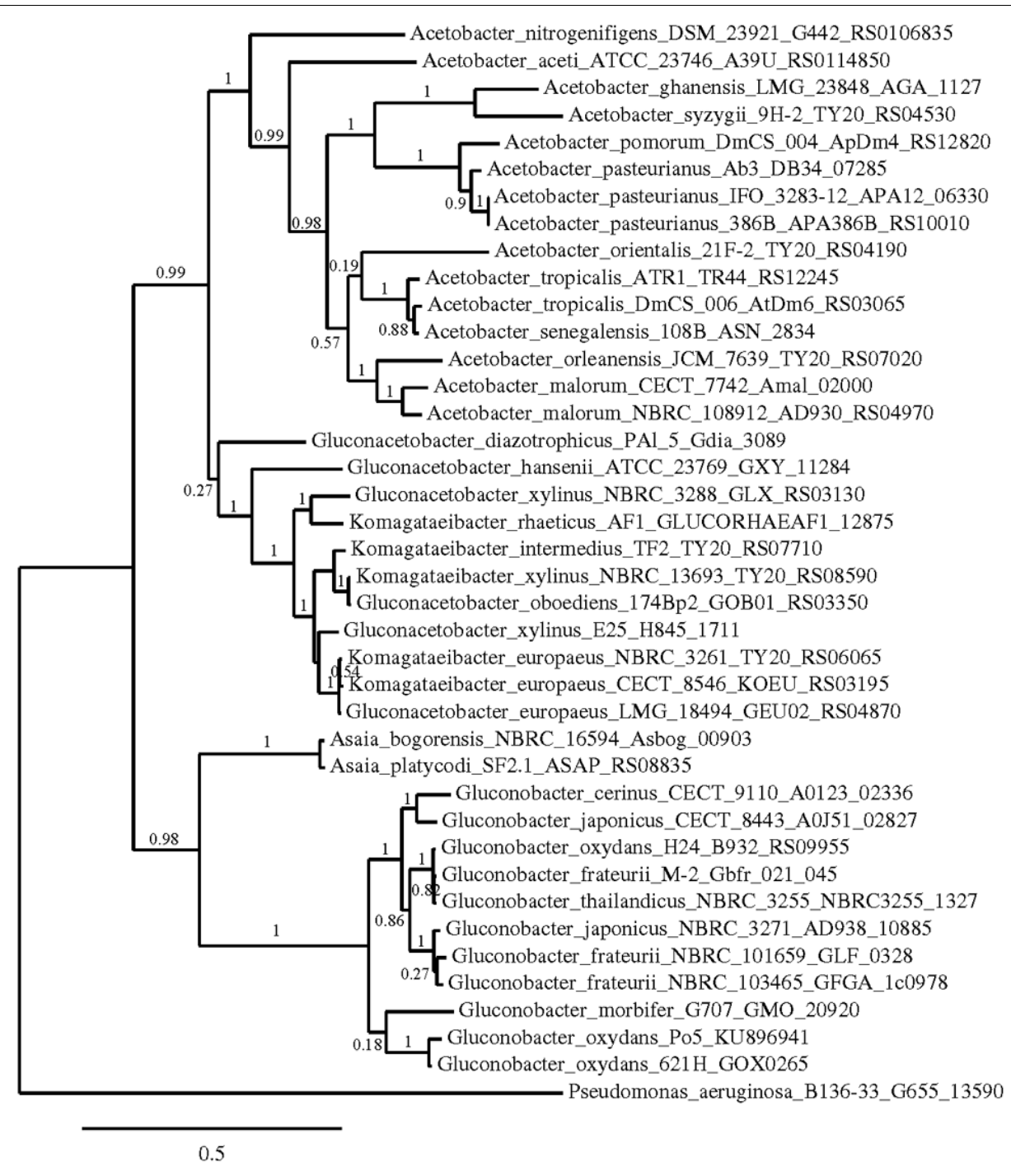

FIGURE 5 | Phylogenetic relationship of $\mathbf{g c d}$ gene in different species of acetic acid bacteria. The entries of different genotypes include the accession numbers of the GeneBank database sequence. The gcd sequence of Pseudomonas aeruginosa B136-33 was used as outgroup. The numbers indicate the branch support values.

G. oxydans sequences, while in the other two clusters, the two homologous GLDH genes (that were amplified by the primer sets of gldh1 and gldh2) of G. japonicus grouped separately.

\section{DISCUSSION}

In a previous study (Sainz et al., 2016), we selected three strains of $\mathrm{AAB}$ capable of oxidizing D-glucose to GA without consuming $\mathrm{D}$-fructose in a puree of strawberry with the aim of developing a new attractive fermented beverage for consumers preserving the fruit natural sweetness. The following three main requirements were decisive for the selection of these strains: a high production of GA, total consumption of D-glucose and minimal oxidation of D-fructose. Because the consumption of Dglucose and D-fructose and the production of GA were observed to be dependent on the strain and the media, the strains were mainly selected based on their behavior in strawberry puree. The selected strains were G. japonicus CECT 8443, G. oxydans Po5 and A. malorum CECT 7742, depending on the desired final product (final concentration of GA and keto-Dgluconates). Understanding the differences in the production of these compounds in these strains could help control the beverage composition in a more effective and reproducible way.

It has been extensively described that $\mathrm{AAB}$ present high numbers of membrane-bound dehydrogenases, classified as quinoproteins and flavoproteins - cytochrome $c$ complex, involved in incomplete oxidation of sugars and alcohols to produce the corresponding sugar acids which are accumulated in the medium (Matsushita et al., 1994, 2004; Adachi et al., 2007). This feature is essential for industrial applications of these organisms (Meyer et al., 2013). In our study, different 


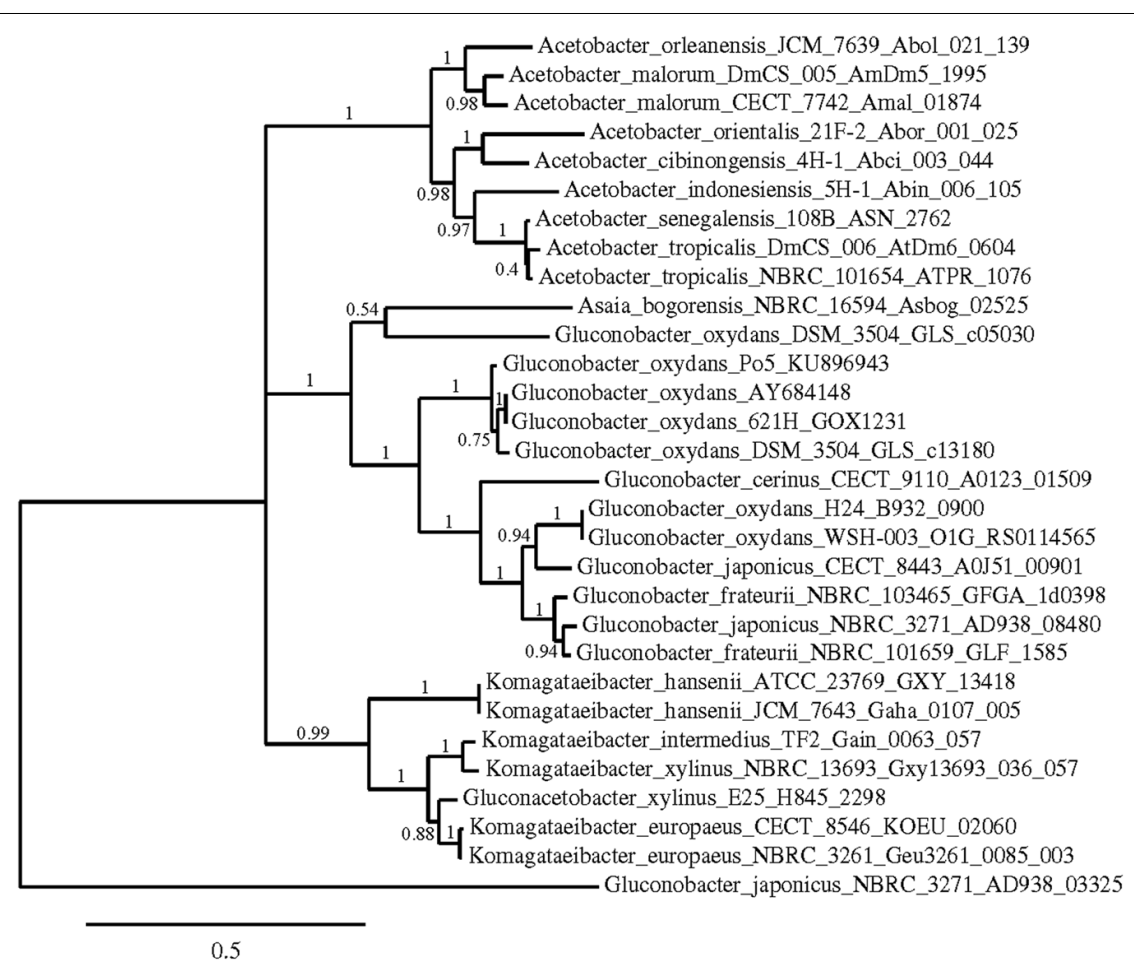

FIGURE 6 | Phylogenetic relationship of gnd $\mathrm{L}$ gene in different species of acetic acid bacteria. The entries of different genotypes include the accession numbers of the GeneBank database sequence. The sequence of one of the genes coding for GADH in Gluconobacter japonicus NBRC 3271 (AD938_03325) was used as outgroup. The numbers indicate the branch support values.

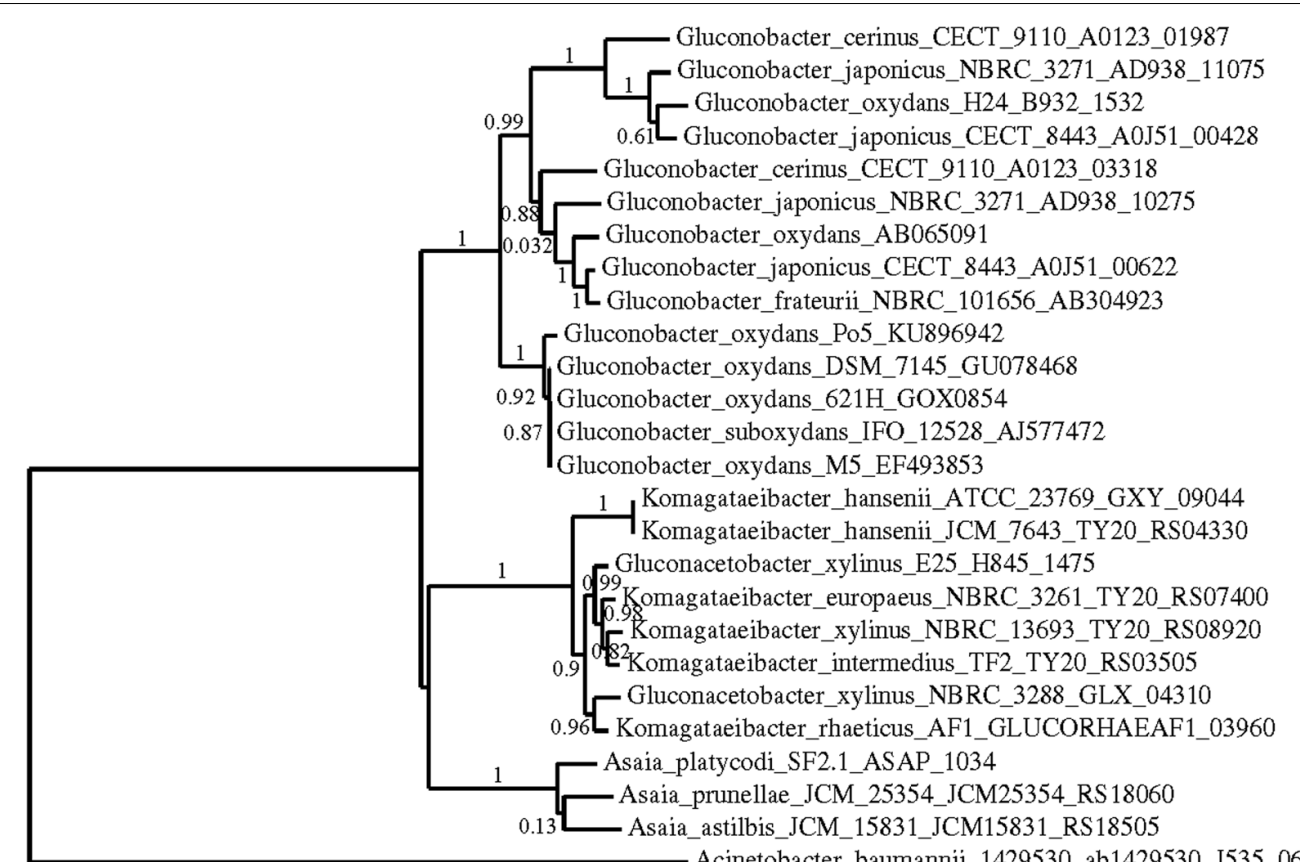

Acinetobacter_baumannii_1429530_ab1429530_J535_0638

0.8

FIGURE 7 | Phylogenetic relationship of sldA gene in different species of acetic acid bacteria. The entries of different genotypes include the accession numbers of the GeneBank database sequence. The sldA sequence of Acinetobacter baumannii 1429530 was used as outgroup. The numbers indicate the branch support values. 
$\mathrm{AAB}$ strains were collected at different growth phases, and the activity of membrane-bound dehydrogenases involved in D-glucose oxidation and the accumulation of corresponding metabolites were studied.

According to the growth of the strains, differences in the maximal population were observed both among species and between strains within the same species, reaching in some cases double the population size. Only G. japonicus strains showed identical growth, achieving the highest population of all the studied species. A low biomass formation has been associated with high oxidation rates (Elfari et al., 2005); the more biomass produced, the less D-glucose used for product formation. Krajewski et al. (2010) explained this low biomass when D-glucose is used as carbon source because most D-glucose is metabolized rapidly to GA and its derivatives in the periplasm, and therefore, it could not be used for biomass formation, just for the generation of proton motive force. In our case, no important differences were observed between the species or strains because D-glucose was completely depleted in all the cases, and the maximal accumulation of GA in the medium was similar, except for strain CECT 7742 belonging to A. malorum that accumulated approximately $30 \mathrm{mM}$ less of GA. In this case, the lower accumulation of GA was compensated by a high concentration of 2KGA. Therefore, there was no correlation between low growth and high GA and keto-D-gluconates production, likely because growth in all cases was low, suggesting that the amount of D-glucose used for biomass was only a minor part of the initial D-glucose, and the differences observed in growth were not reflected in metabolite production. This low growth confirms that the oxidation of D-glucose to GA and keto-D-gluconates has a negative effect on the growth rate and the growth yield as stated by Krajewski et al. (2010) for G. oxydans.

All strains accumulated GA in the medium, being maximal at $24 \mathrm{~h}$, in parallel with the maximal activity of $\mathrm{mGDH}$. This high enzyme activity at the late exponential phase and its subsequent decrease agree with the findings of Matsushita et al. (1980), who described that mGDH activity reached the maximum activity in the mid-to late exponential phase of cultivation and then decreased with progress of growth. Ameyama et al. (1981) observed that the higher formation of this enzyme was achieved at the late exponential phase, between 24 and $30 \mathrm{~h}$, depending on the fermenter used, when AAB grew on a medium containing D-glucose, glycerol and sodium-D-gluconate. The activity levels obtained in this study are consistent with those found in the literature (Ameyama et al., 1981; Matsushita et al., 1987, 1989; Meyer et al., 2013), showing similar or even higher values. Important differences in mGDH activity among strains were observed, and these differences were especially relevant in the case of selected Gluconobacter strains with a high activity along the process in comparison to culture collection strains. However, in practically all cases, similar GA concentrations were detected, probably due to a limitation of substrate (D-glucose) in the media. Moreover, as the first sampling point of activity (24 h) already showed the highest enzyme activity, a similar evolution over time was observed in the enzyme activities between strains.

Regarding GADH, all our tested strains showed GADH activity. Shinagawa et al. (1976) previously reported this activity in the cell free extracts in strains of Gluconobacter and Acetobacter together with strains from other bacteria (Pseudomonas aeruginosa, Klebsiella pneumoniae and Serratia marcescens). In our study, G. japonicus NBRC 3271 presented the highest activity of GADH and the highest accumulation of $2 \mathrm{KGA}$, whereas $G$. oxydans strains did not accumulate any 2KGA despite presenting small activity only at $24 \mathrm{~h}$. Strains from different species of the Gluconobacter genus are reported to accumulate high concentrations of 2KGA and/or 5KGA from D-glucose or GA without any appreciable assimilation into cells (Sievers and Swings, 2005). Moreover, a sequential accumulation of GA and keto-D-gluconates during the growth of G. oxydans $621 \mathrm{H}$ and other Gluconobacter species on D-glucose media with controlled pH has been described (Weenk et al., 1984), which is in agreement with our results. However, Levering et al. (1988) showed that $G$. oxydans $621 \mathrm{H}$ growing in yeast extract medium containing $50 \mathrm{mM}$ D-glucose was able to oxidize quantitatively D-glucose to GA, without the production of $2 \mathrm{KGA}$ and 5KGA, similar to our observations with strain Po5. This lack of ketoD-gluconates synthesis in some strains has been associated with the fact that during the first phase of growth on D-glucose in batch cultures, the oxidation of D-glucose by mGDH was so rapid that the respiratory chain becomes saturated. For this reason, the ubiquinone was unable to accept electrons from $\mathrm{GADH}$, resulting in the impossibility of oxidizing the GA in these conditions (Levering et al., 1988). Therefore, strain Po5, with high production of GA but no accumulation of keto-Dgluconates, appeared to be the best strain to obtain and maintain high concentrations of GA in the fermented beverage. In our previous study (Sainz et al., 2016), we tested different media, and this strain was the strain with the highest production of GA and the lowest production of keto-D-gluconates. Diverse studies in Gluconobacter strains showed differences in the rate of $2 \mathrm{KGA}$ or 5KGA from D-glucose (Weenk et al., 1984; Silberbach et al., 2003; Herrmann et al., 2004; Elfari et al., 2005). The individual product yields vary among different strains and depend also on the media and on the particular conditions used for cultivation (Asai, 1968; Olijve and Kok, 1979). GLDH and GADH enzymes compete for the oxidation of GA; therefore, selective expression of either dehydrogenase could increase the production of either of the keto-D-gluconates (Matsushita et al., 2003; Elfari et al., 2005). In our conditions, only G. japonicus strains were able to accumulate both keto-D-gluconates. These strains present two genes for GLDH, and strain NBRC 3271 also presents two genes for GADH. However, strain CECT 8443 has only one gene for GADH with a sequence similar to the gene, which was amplified with primers gadh1 of strain NBRC3271.

Gluconobacter oxydans $621 \mathrm{H}$ only accumulated 5KGA. In other studies and culture conditions, $621 \mathrm{H}$ exhibited different keto-D-gluconate synthesis profiles, varying from the accumulation of both keto-D-gluconates (Weenk et al., 1984) or no keto-D-gluconates synthesis, confirming that culture conditions are essential for the synthesis of these compounds. The other strain belonging to G. oxydans, Po5, did not accumulate any keto-D-gluconate, despite having a similar GLDH activity to $621 \mathrm{H}$. A lack of amplification of the GLDH gene (sldA) was observed in this strain (Po5). The $621 \mathrm{H}$ sldA sequence 
was used for the design of the primers, and although this gene sequence in both strains is similar (>96\%), there are some nucleotide differences in the region where the reverse primer hybridized (results not shown). In G. japonicus, strain NBRC 3271 showed the highest GLDH activity at $24 \mathrm{~h}$ and after a decrease, although the 5KGA concentration was increasing until 48 h. Instead, in CECT 8443, the increase in GLDH activity between 24 and $48 \mathrm{~h}$ was correlated with the increase in the 5KGA accumulation. A. malorum strains presented both activities (GADH and GLDH), but no accumulation of 5KGA was detected. A lack of 5KGA synthesis was expected according to the A. malorum description (synthesis of $2 \mathrm{KGA}$ and lack of 5KGA synthesis) (Cleenwerck et al., 2002). However, the activity detected in this study together with the accumulation of this compound by strain CECT 7742 in a previous study (Sainz et al., 2016) appear to confirm that this species or some strains belonging to this species are able to synthesize 5KGA. It has to be emphasized that this previous production of 5KGA was observed in different medium conditions. The absence of the sld $A$ sequence in the $A$. malorum genome appears to suggest the possibility that other enzymes for the synthesis of this compound are used. Furthermore, strain NBRC 108912 showed a high decrease in the GA concentration that cannot be only accounted for the oxidation to $2 \mathrm{KGA}$. Nevertheless, the products of $\mathrm{D}$-glucose oxidation have been reported to be assimilated by cytoplasmic reductases during the stationary phase, and then introduced to the pentose-phosphate pathway to produce cell biomass (Saichana et al., 2015). However, this would have as consequence a second phase of growth that was not observed in our case.

A phylogenetic study using the sequences of these three key enzymes for D-glucose oxidation in $\mathrm{AAB}$ was performed; in all the cases, trees that showed clear clusters according to the genus were obtained. Gene gcd was the one with more sequences available in the GenBank database, allowing for a more reliable study. Based on the $g c d$ sequences, the Acetobacter and Komagataeibacter species seemed to be more closely related, and Gluconobacter was more related to Asaia, which is different to the findings obtained using the $16 \mathrm{~S}$ rRNA gene sequence (Yamada et al., 2012). However, this difference should not be surprising because the D-glucose metabolism of these two genera is closer than in the other genera, which have a higher preference for other substrates, such as ethanol. The Gluconobacter and Asaia genera were reported to develop better in media enriched with sugar (Raspor and Goranovic, 2008), with high oxidation activity of sugar and sugar alcohols (D-glucose, GA, D-sorbitol, and glycerol). In addition, Matsutani et al. (2011) claimed that the Acetobacter and Komagataeibacter species are more closely related to each other than Gluconobacter by whole genome level phylogenetic analysis. Therefore, our results agree with this previous work.

For our results, the concentrations of D-glucose and GA show an effective, almost equimolar conversion, which takes place during the first $24 \mathrm{~h}$ and is likely to the end of the exponential phase of growth (Matsushita et al., 1980; Ameyama et al., 1981). At this time, the $\mathrm{mGDH}$ activity is the highest during the studied period. The absence of the main substrate makes its activity unnecessary and therefore declines afterward. It could be assumed that during the first $24 \mathrm{~h}$, the high activity of this enzyme accounts for the full transformation of D-glucose into GA, which occurs in all the species and strains observed. However, the transformation of GA is heavily dependent on the species and the strain (Asai, 1968; Olijve and Kok, 1979; Weenk et al., 1984). Regardless of the presence of the activities of GADH and GLDH in G. oxydans natural strain Po5, no further oxidation of GA to keto-D-gluconates was observed. In fact, no production of 5-KGA was detected despite the high activity of GLDH in G. oxydans, showing a lack of correlation between the activity and products that could be explained by the lack of specificity of this enzyme (Matsushita et al., 2003) Instead, the absence of GADH activity after $24 \mathrm{~h}$ correlated with the lack of $2 \mathrm{KGA}$ production in both G. oxydans strains. In G. japonicus and A. malorum, the production of $2 \mathrm{KGA}$ was always observed, although no correlation could be found between the activity and the products. However, when activity of GADH was detected after $24 \mathrm{~h}$, albeit it was low, important accumulation of $2 \mathrm{KGA}$ in the medium was observed (higher than $50 \mathrm{mM}$ ). Comparing between the three selected strains, important differences were observed at the activity level of these enzymes. Both Gluconobacter strains (CECT 8443 and Po5) presented a very high activity of $\mathrm{mGDH}$ at $24 \mathrm{~h}$, with a further decrease and low activity in the GADH and GLDH but with changes overtime, whereas CECT 7742 presented in the three enzymes a low activity but maintained practically constant throughout all the time.

The possible use of these different strains and species for the production of different concentrations of GA and its derivatives could be achieved through the thorough knowledge of the activity and the expression of the enzymes. However, our results also indicate that the conditions of the process and the composition of the medium are crucial to the final composition of the product because important differences were observed in the synthesis profile of these strains in different media or conditions (Sainz et al., 2016). Therefore, a next step should be the analysis of the expression of these genes (especially mGDH and GADH) in different conditions to fully understand and control the process of the oxidation of D-glucose by AAB.

\section{AUTHOR CONTRIBUTIONS}

FS, MJT, KM, and AM Design and draft the work, interpret the data and wrote the final version. FS and MJT performed and analyzed the experimental work. MM, NK, and TY helped in the experimental work, revised critically the manuscript and approved the final version.

\section{ACKNOWLEDGMENTS}

This work was supported by the grant AGL2010-22152-C03-02 from the Spanish Ministry of Science and Innovation. FS holds a FI Fellowship from the Agència de Gestió d'Ajuts Universitaris i de Recerca (AGAUR), Government of Catalonia. 


\section{REFERENCES}

Adachi, O., Ano, Y., Toyama, H., and Matsushita, K. (2007). "Biooxidation with PQQ- and FAD-dependent dehydrogenases," in Modern Biooxidation Enzymes, Reactions and Applications, eds R. D. Schmid and V. B. Urlacher (Weinheim: Wiley-vch Verlag GmbH \& Co KGaA).

Adachi, O., Moonmangmee, D., Toyama, H., Yamada, M., Shinagawa, E., and Matsushita, K. (2003). New developments in oxidative fermentation. Appl. Microbiol. Biotechnol. 60, 643-653. doi: 10.1007/s00253-002-1155-9

Ameyama, M., Shinagawa, E., Matsushita, K., and Adachi, O. (1981). D-Glucose dehydrogenase of Gluconobacter suboxydans: solubilization, purification and characterization. Agr. Bio. Chem. 45, 851-861. doi: $10.1080 / 00021369.1981 .10864633$

Asai, T. (1968). Acetic Acid Bacteria: Classification and Biochemical Activities. Tokyo: University of Tokyo Press.

Asano, T., Yuasa, K., Kunugita, K., Teraji, T., and Mitsuoka, T. (1994). Effects of gluconic acid on human faecal bacteria. Microb. Ecol. Health Dis. 7, 247-256. doi: 10.3109/08910609409141362

Asano, T., Yuasa, K., Yoshimura, Y., Takenawa, S., and Fukuba, H. (1997). Digestion, absorption and intestinal residue of various gluconic acids in rats. J. Jp. Soc. Nutr. Food Sci. 50, 287-294. doi: 10.4327/jsnfs. 50.287

Cañete-Rodríguez, A. M., Santos-Dueñas, I. M., Jiménez-Hornero, J. E., Torija, M. J., Mas, A., and García-García, I. (2016). Revalorization of strawberry surpluses by bio-transformation its glucose content into gluconic acid. Food Bioprod. Process. 99, 188-196. doi: 10.1016/j.fbp.2016.05.005

Cañete-Rodríguez, A. M., Santos-Dueñas, I. M., Torija, M. J., Mas, A., Jiménez-Hornero, J. E., and García-García, I. (2015). Preparation of a pure inoculum of acetic acid bacteria for the selective conversion of glucose in strawberry purée into gluconic acid. Food Bioprod. Process. 96, 35-42. doi: 10.1016/j.fbp.2015.06.005

Castresana, J. (2000). Selection of conserved blocks from multiple alignments for their use in phylogenetic analysis. Mol. Biol. Evol. 17, 540-552. doi: 10.1093/oxfordjournals.molbev.a026334

Cleenwerck, I., Vandemeulebroecke, K., Janssens, D., and Swings, J. (2002). Re-examination of the genus Acetobacter, with descriptions of Acetobacter cerevisiae sp. nov and Acetobacter malorum sp. nov. Int. J. Syst. Evol. Microbiol. 52, 1551-1558. doi: 10.1099/ijs.0.02064-0

De Ley, J. (1961). Comparative carbohydrate metabolism and a proposal for the phylogenetic relationship of the acetic acid bacteria. J. Gen. Microbiol. 24, 31-50. doi: 10.1099/00221287-24-1-31

De Ley, J., and Swings, J. (1984). "Genus Gluconobacter," in Bergey's Manual of Systematic Bacteriology, eds N. R. Kreig and J. G. Holt (Philadelphia, PA: Williams and Wilkins), 275-278.

Deppenmeier, U., Hoffmeister, M., and Prust, C. (2002). Biochemistry and biotechnological applications of Gluconobacter strains. App. Microbiol. Biotechnol. 60, 233-242. doi: 10.1007/s00253-002-1114-5

Dereeper, A., Audic, S., Claverie, J. M., and Blanc, G. (2010). BLAST-EXPLORER helps you building datasets for phylogenetic analysis. BMC Evol. Biol. 10:8. doi: 10.1186/1471-2148-10-8

Dereeper, A., Guignon, V., Blanc, G., Audic, S., Buffet, S., Chevenet, F., et al. (2008). Phylogenyfr: robust phylogenetic analysis for the non-specialist. Nucleic Acids Res. 36, 465-469. doi: 10.1093/nar/gkn180

Dulley, J. R., and Grieve, P. A. (1975). A simple technique for eliminating interference by detergents in the lowry method of protein determination. Anal. Biochem. 64, 136-141. doi: 10.1016/0003-2697(75)90415-7

Edgar, R. C. (2004a). MUSCLE: a multiple sequence alignment method with reduced time and space complexity. BMC Bioinformatics 5:113. doi: 10.1186/1471-2105-5-113

Edgar, R. C. (2004b). MUSCLE: multiple sequence alignment with high accuracy and high throughput. Nucleic Acids Res. 32, 1792-1797. doi: 10.1093/nar/gkh340

Elfari, M., Ha, S. W., Bremus, C., Merfort, M., Khodaverdi, V., Herrmann, U., et al. (2005). A Gluconobacter oxydans mutant converting glucose almost quantitatively to 5-keto-D-gluconic acid. App. Microbiol. Biotechnol. 66, 668674. doi: 10.1007/s00253-004-1721-4

Gupta, A., Singh, V. K., Qazi, G. N., and Kumar, A. (2001). Gluconobacter oxydans: it's biotechnological applications. J. Mol. Microbiol. Biotechnol. 3, 445-456.
Herrmann, U., Merfort, M., Jeude, M., Bringer-Meyer, S., and Sahm, H. (2004). Biotransformation of glucose to 5-keto-D-gluconic acid by recombinant Gluconobacter oxydans DSM 2343. App. Microbiol. Biotechnol. 64, 86-90. doi: 10.1007/s00253-003-1455-8

Hidalgo, C., Torija, M. J., Mas, A., and Mateo, E. (2013). Effect of inoculation on strawberry fermentation and acetification processes using native strains of yeast and acetic acid bacteria. Food Microbiol. 34, 88-94. doi: 10.1016/j.fm.2012.11.019

Krajewski, V., Simic, P., Mouncey, N. J., Bringer, S., Sahm, H., and Bott, M. (2010). Metabolic engineering of Gluconobacter oxydans for improved growth rate and growth yield on glucose by elimination of gluconate formation. Appl. Environ. Microb. 76, 4369-4376. doi: 10.1128/AEM.03022-09

Levering, P. R., Weenk, G., Olijve, W., Dijkhuizen, L., and Harder, W. (1988). Regulation of gluconate and ketogluconate production in Gluconobacter oxydans ATCC 621-H. Arch. Microbiol. 149, 534-539. doi: 10.1007/BF00446757

Lino, T., Suzuki, R., Kosako, Y., Ohkuma, M., Komagata, K., and Uchimura, T. (2012). Acetobacter okinawensis sp.nov, Acetobacter papayae sp.nov, and Acetobacter persicus sp.nov; novel acetic acid bacteria isolated from stems of sugarcane, fruits, and a flower in Japan. J. Gen. App. Microbiol. 58, 235-243. doi: 10.2323/jgam.58.235

Macauley, S., McNeil, B., and Harvey, L. M. (2001). The genus Gluconobacter and its applications in biotechnology. Cri. Rev. Biotechnol. 21, 1-25. doi: $10.1080 / 20013891081665$

Malimas, T., Yukphan, P., Takahashi, M., Muramatsu, Y., Kaneyasu, M., Potacharoen, W., et al. (2009). Gluconobacter japonicus sp.nov, an acetic acid bacterium in the Alphaproteobacteria. Int. J. Syst. Evol. Microbiol. 59, 466-471. doi: 10.1099/ijs.0.65740-0

Matsushita, K., and Ameyama, M. (1982). D-glucose dehydrogenase from Pseudomonas fluorescens, membrane-bound. Methods Enzymol. 89, 149-154. doi: 10.1016/S0076-6879(82)89026-5

Matsushita, K., Fujii, Y., Ano, Y., Toyama, H., Shinjoh, M., Tomiyama, N., et al. (2003). 5-Keto-D-Gluconate production is catalyzed by a quinoprotein glycerol dehydrogenase, major polyol dehydrogenase, in Gluconobacter species. Appl. Environ. Microb. 69, 1959-1966. doi: 10.1128/AEM.69.4.1959-1966.2003

Matsushita, K., Nonobe, M., Shinagawa, E., Adachi, O., and Ameyama, M. (1987). Reconstitution of pyrroloquinoline quinone-dependent D-glucose oxidase respiratory chain of Escherichia coli with cytochrome o oxidase. J. Bacteriol. 169, 205-209.

Matsushita, K., Shinagawa, E., Adachi, O., and Ameyama, M. (1989). Quinoprotein $\mathrm{D}$-glucose dehydrogenase of the Acinetobacter calcoaceticus species respiratory chain: membrane-bound and soluble forms are different molecular species. Biochemistry 28, 6276-6280. doi: 10.1021/bi00441a020

Matsushita, K., Toyama, H., and Adachi, O. (1994). "Respiratory chains and bioenergetics of acetic acid bacteria," in Advances in Microbial Physiology, eds A. H. Rose and D. W. Tempest (London: Academic Press Ltd), 247-301.

Matsushita, K., Toyama, H., and Adachi, O. (2004). "Respiratory chains in acetic acid bacteria: Membrane-bound periplasmic sugar and alcohol respirations," in Respiration in Archea and Bacteria Vol 2: Diversity of Prokaryotic Respiratory Systems, ed. D. Zannoni (Dordrecht: Springer).

Matsushita, K., Yamada, M., Shinagawa, E., Adachi, O., and Ameyama, M. (1980). Membrane-bound respiratory chain of Pseudomonas aeruginosa grown aerobically. J. Bacteriol. 141, 389-392.

Matsutani, M., Hirakawa, H., Yakushi, T., and Matsushita, K. (2011). Genome-wide phylogenetic analysis of Gluconobacter, Acetobacter, and Gluconacetobacter. FEMS Microbiol. Lett. 315, 122-128. doi: 10.1111/j.1574-6968.2010.02180.x

Merfort, M., Herrmann, U., Bringer-Meyer, S., and Sahm, H. (2006). Highyield 5-keto-D-gluconic acid formation is mediate by soluble and membranebound gluconate-5-dehydrogenases of Gluconobacter oxydans. App. Microbiol. Biotechnol. 73, 443-451. doi: 10.1007/s00253-006-0467-6

Meyer, M., Schweiger, P., and Deppenmeier, U. (2013). Effects of membranebound glucose dehydrogenase overproduction on the respiratory chain of Gluconobacter oxydans. App. Microbiol. Biotechnol. 97, 3457-3466. doi: 10.1007/s00253-012-4265-z

Navarro, D., Mateo, E., Torija, M. J., and Mas, A. (2013). Acetic acid bacteria in grape must. Acetic Acid Bacteria 2, 19-23. doi: 10.4081/aab.2013.s1.e4

Olijve, W., and Kok, J. J. (1979). Analysis of growth of Gluconobacter oxydans in glucose containing media. Arch. Microbiol. 121, 283-290. doi: 10.1007/BF00425070 
Prust, C., Hoffmeister, M., Liesegang, H., Wiezer, A., Fricke, W. F., Ehrenreich, A., et al. (2005). Complete genome sequence of the acetic acid bacterium Gluconobacter oxydans. Nat. Biotechnol. 23, 195-200. doi: 10.1038/nbt1062

Ramachandran, S., Fontanille, P., Pandey, A., and Larroche, C. (2006). Gluconic acid: properties, applications and microbial production. Food Technol. Biotechnol. 44, 185-195. doi: 10.1002/bit.25978

Raspor, P., and Goranovic, D. (2008). Biotechnological applications of acetic acid bacteria. Crit. Rev. Biotechnol. 28, 101-124. doi: 10.1080/07388550802046749

Saichana, N., Matsushita, K., Adachi, O., Frébort, I., and Frebortova, J. (2015). Acetic acid bacteria: a group of bacteria with versatile biotechnological applications. Biotechnol. Adv. 33, 1260-1271. doi: 10.1016/j.biotechadv. 2014.12.001

Sainz, F., Navarro, C., Mateo, E., Torija, M. J., and Mas, A. (2016). Comparison of D-gluconic acid production in selected strains of acetic acid bacteria. Int. J. Food Microbiol. 222, 40-47. doi: 10.1016/j.ijfoodmicro.2016.01.015

Shinagawa, E., Chiyonobu, T., Adachi, O., and Ameyama, M. (1976). Distribution and solubilization of particulate gluconate dehydrogenase and particulate 2ketogluconate dehydrogenase in acetic acid bacteria. Agr. Biol. Chem. 40, 475-483. doi: 10.1080/00021369.1976.10862088

Shinagawa, E., Matsushita, K., Toyama, H., and Adachi, O. (1999). Production of 5-keto-D-gluconate by acetic acid bacteria is catalyzed by pyrroloquinoline quinone (PQQ)-dependent membrane-bound D-gluconate dehydrogenase. J. Mol. Catal. B Enzym. 6, 341-350. doi: 10.1016/S1381-1177(98)00112-X

Sievers, M., and Swings, J. (2005). "Family Acetobacteriaceae Gills and De Loy 1980," in Bergey's Manual of Systematic Bacteriology, eds G. M. Garrity, M. Winters, and D. B. Searles (NewYork, NY: Springer).

Silberbach, M., Maier, B., Zimmermann, M., and Buchs, J. (2003). Glucose oxidation by Gluconobacter oxydans: characterization in shaking-flasks, scaleup and optimization of the pH profile. App. Microbiol. Biotechnol. 62, 92-98. doi: $10.1007 / \mathrm{s} 00253-003-1222-\mathrm{x}$

Talavera, G., and Castresana, J. (2007). Improvement of phylogenies after removing divergent and ambiguously aligned blocks from protein sequence alignments. Syst. Biol. 56, 564-577. doi: 10.1080/10635150701472164

Toyama, H., Furuya, N., Saichana, I., Ano, Y., Adachi, O., and Matsushita, K. (2007). Membrane-bound, 2-keto-D-gluconate-yielding D-gluconate dehydrogenase from "Gluconobacter dioxyacetonicus" IFO 3271: molecular properties and gene disruption. Appl. Environ. Microb. 73, 6551-6556. doi: 10.1128/AEM.00493-07

Tsukahara, T., Koyama, H., Okada, M., and Ushida, K. (2002). Stimulation of butyrate production by gluconic acid in batch culture of pig cecal digesta and identification of butyrate-producing bacteria. J. Nutr. 132, 2229-2234.

Untergasser, A., Nijveen, H., Rao, X., Bisseling, T., Geurts, R., and Leunissen, J. A. (2007). Primer3Plus, an enhanced web interface to Primer3. Nucleic Acids. Res. 35, 71-74. doi: 10.1093/nar/gkm306

Vegas, C., Mateo, E., González, A., Jara, C., Guillamón, J. M., Poblet, M., et al. (2010). Population dynamics of acetic acid bacteria during traditional wine vinegar production. Int. J. Food Microbiol. 138, 130-136. doi: 10.1016/j.ijfoodmicro.2010.01.006

Weenk, G., Olijve, W., and Harder, W. (1984). Ketogluconate formation by Gluconobacter species. App. Microbiol. Biotechnol. 20, 400-405. doi: 10.1007/BF00261942

Wood, W. A., Fetting, R. A., and Hertlein, B. C. (1962). "Gluconic dehydrogenase from Pseudomonas fluorescens," in Methods in Enzymology, vol V, eds S. P. Colowick and N. O. Kaplan (New York, NY: Academic Press Inc), 287-291.

Yamada, Y., Yukphan, P., Lan Vu, H. T., Muramatsu, Y., Ochaikul, D., and Nakagawa, Y. (2012). Subdivision of the genus Gluconacetobacter Yamada, Hoshino and Ishikawa 1998: the proposal of Komagatabacter gen. nov, for strains accommodated to the Gluconacetobacter xylinus group in the $\alpha$-Proteobacteria. Ann. Microbiol. 62, 849-859. doi: 10.1007/s13213-0110288-4

Conflict of Interest Statement: The authors declare that the research was conducted in the absence of any commercial or financial relationships that could be construed as a potential conflict of interest.

Copyright (c) 2016 Sainz, Torija, Matsutani, Kataoka, Yakushi, Matsushita and Mas. This is an open-access article distributed under the terms of the Creative Commons Attribution License (CC BY). The use, distribution or reproduction in other forums is permitted, provided the original author(s) or licensor are credited and that the original publication in this journal is cited, in accordance with accepted academic practice. No use, distribution or reproduction is permitted which does not comply with these terms. 